\title{
Effectiveness of Sodium Bentonite Clay for Reducing Seepages from Earthen Rainwater Harvesting Ponds
}

\author{
${ }^{1}$ Pakistan Council of Research in Water Resources, Pakistan \\ ${ }^{2}$ Prince Edwards Islands University, Canada \\ Submission: June 21, 2021; Published: July 19, 2021 \\ *Corresponding author: Bareerah Fatima, Pakistan Council of Research in Water Resources, Pakistan
}

Muhammad Ashraf ${ }^{1}$, Bareerah Fatima ${ }^{1 *}$, Faizan ul Hasan ${ }^{1}$, Ahmad Zeeshan Bhatti ${ }^{2}$ and Arslan Mumtaz ${ }^{1}$

\section{Abstract}

In drylands, livelihood entirely depends on rainwater, which is mostly stored in surface earthen ponds. However, the seepage and evaporation losses from these ponds reduce their effectiveness. A number of techniques have been tried to reduce seepage losses such as mud plaster, laying polythene sheets etc. However, their cost-effectiveness and sustainability remained questionable. In this research, a series of experiments were conducted to determine effectiveness of bentonite clay in reducing seepage from the bed and side walls of trapezoidal dug off ponds. Each experiment was replicated thrice. Water level in the pond was maintained at $0.40 \mathrm{~m}$ depth by refilling it frequently and recording seepagerate. The seepage rates were initially higher and gradually declined to attain steady state in almost four hours. The final seepage rates were compared to find the most effective treatment. It was found that sodium bentonite can exclusively seal the beds of the ponds. The $2.5 \mathrm{~cm}$ thick layer composed of $50 \%$ sodium bentonite, $25 \%$ soil (sandy loam) and $25 \%$ chopped wheat straw was found to be the most appropriate material for pond lining.

Keywords: Sodium bentonite clay; Infiltration rate; Rainwater harvesting; Seepage rate; Dry areas

\section{Introduction}

Arid lands constitute around $80 \%$ of the world's agricultural land where livelihood entirely depends on rainwater. These areas however, contribute at least two-third of global food production [1]. About $70 \%$ of the world's poor people live in these areas. These areas however, have a great potential to contribute to livelihood and food security of the poorest due to:

(i) wide gap between current level of agricultural productivity and its potential,

(ii) largely belong to poor communities and

(iii) large area available for out-scaling of promising interventions. Therefore, these lands need to be exploited to meet the ever-increasing food and fiber demands [2].

Pakistan is an arid country where rainfall varies from less than $100 \mathrm{~mm}$ to over $1000 \mathrm{~mm}$. Out of the 30 Mha culturable land, 12 Mha (40\%) is rainfed where livelihood entirely depends on rainwater [3]. Rainwater harvesting, management and its use is a common practice for drinking and farming, either directly tapping the runoff or storing it in surface or subsurface reservoirs [4].
Many studies have reported rainwater harvesting as a potential decentralized storage option for drinking (human and livestock), supplemental irrigation and climate change adaptation. Their design, effectivness, performance and associated costs vary from region to region [5-8].

Climate change may affect the rainfall variability in terms of intensity and duartion. This in turn would have severe impacts on the livelihood of the local community particularly in drylands. Rainwater ponds provide a buffer against climate induced varibilities and droughts. Therefore, management of the stored water in the ponds becomes imperative. For sustainable and long term use of the rainwater, it is important to minimize the seepage and evaporation losses in these ponds.

Various kind of material have been used to line these ponds such as mud plastering, polythene sheeting, brick lining etc. However, these options have their own challenges like cost, stability, life, efficiencies, diversion requirements etc $[4,9,10]$. Bentonite is impure clay, which is normally found in nature in combination with either of potassium, sodium, calcium, aluminum and silicate $\left(\mathrm{Al}_{2} \mathrm{H}_{2} \mathrm{Na}_{2} \mathrm{O}_{13} \mathrm{Si}_{4}\right)$. Each form has certain characteristics 
and is therefore, used accordingly [11]. This clay contains montmorillonite as the essentail mineral having the siginificant feature of swelling when mixed with water [12]. It can be mixed with existing soils and compacted in layers. Upon wetting, bentonite clay tends to seal soil due to its high swelling properties. Only Sodium Bentonite Clay (SBC) can be used to line ponds and reserviors [13] and it can be applied in slurry or blanketing. The SBC soil mixuture layer should be covered with local soil to avoid floating and flowing off of the caly particle [14]. In Pakistan, it is extracted mostly in Khuzdar and is available in the market at nominal cost @ Rs.1,050/ton (about US\$ 6-7/ton). The purpose of this study is to determine the effectiveness of Sodium Bentonite clay as a lining material for rainwater harvesting ponds.

\section{Materials and Methods}

The experiments were conducted at research and demonstation station located in district Rawalpindi. The station is operated by Pakistan Council of Research in Water Resources (PCRWR). The annual rainfall in the region is around $1000 \mathrm{~mm}$ and the area is known to yield high sediments. Moreover, the soils have low water holding capacity and gives out high seepage losses. The infiltration rate of the sandy loam soil is around 20$30 \mathrm{~mm} / \mathrm{hr}[15,16]$. Therefore, during the experimentation period
(April-June 2016), record of weather parameters; maximum/ minimum temperature, precipitation and pan evaporation were also maintained at an automatic weather station installed in the Experimentation site. Moreover, cumulative infiltration (F) and infiltration rate $\left(f_{p}\right)$ of the soil being experimented upon was also conducted in field and in laboratory using Horton's infiltration equation (1940); [17]

$$
\begin{aligned}
& F\left(t_{p}\right)=f_{c} t_{p}+\frac{f_{o}-f_{c}}{k}\left(1-e^{-k t p}\right) . \\
& f_{p}=f_{c}+\left(f_{o}+f_{c}\right) e^{-k t p}
\end{aligned}
$$

Where, $\mathrm{F}$ is measured in $(\mathrm{mm})$ and $\mathrm{f}_{\mathrm{p}}$ in $(\mathrm{mm} / \mathrm{hr})$ at a given time, $f_{o}$ stands for initial infiltration rate $(\mathrm{mm} / \mathrm{hr}), \mathrm{f}_{\mathrm{c}}$ denotes steady state infiltration rate $(\mathrm{mm} / \mathrm{hr})$ and $\mathrm{k}$ is the decay constant specific to soil. Moisture holding properties of the local soil was determined using Pressure Plate Extractors. In this test, undisturbed soil samples were placed between the ceramic plates of extractor for designated range of measurement, 1000, 5000 and $15000 \mathrm{~cm}$ in case of this particular experiment.

A total of five experimental trials were designed on five experimental ponds developed at a spacing of six meters (Figure 1). A trapezoidal design was chosen having the specifications; surface area $(1.50 \mathrm{~m} \times 1.50 \mathrm{~m})$, bed area $(0.60 \mathrm{~m} \times 0.60 \mathrm{~m})$ and depth of $0.46 \mathrm{~m}$.

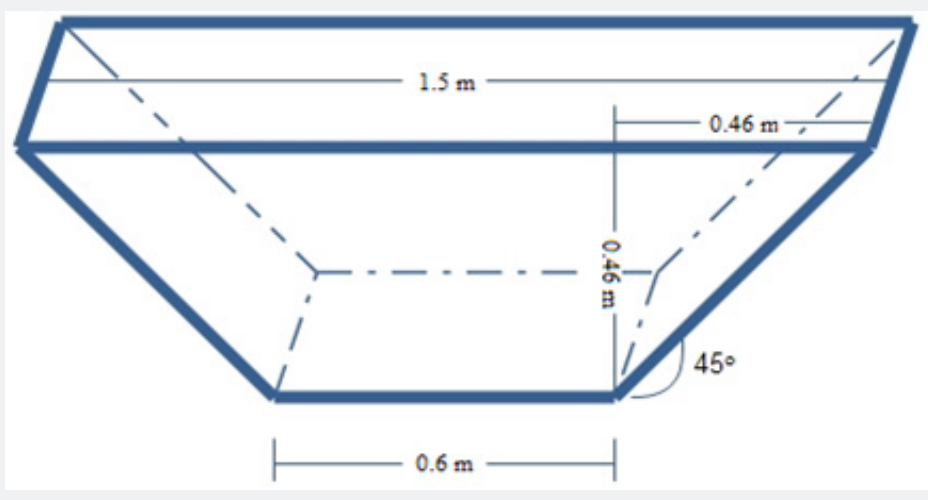

Figure 1: Schematic diagram of the experimental pond.

There were two reasons behind choosing trapezoidal section for the experimental pond. Firstly, it is the design mostly followed by the stakeholders of the rainfed areas for their rainwater harvesting ponds. Secondly, with the sidewalls inclination at $45^{\circ}$, the weight of water over the slanted walls would compensate the buoyancy of the swelled fragments. In this way, stability of the treatment layers over the sidewalls of the experimental earthen ponds is increased.

All rocks, trash, and vegetation including trees and roots from the surfaces (bed and sidewalls) were removed. In each of the trial pond, different lining configurations were tested (Table 1).

Table 1: Description of Sodium Bentonite lining trials.

\begin{tabular}{|c|c|c|}
\hline Experiment & Lining Composition & Sodium Bentonite Clay (SBC) (\%) \\
\hline Test 1 (T1) & Earthen & 0 \\
\hline Test 2 (T2) & Sodium bentonite clay, Sandy loam soil (25\%), Chopped wheat straw (25\%) & 50 \\
\hline Test 3 (T3) & Sodium bentonite clay, Sandy loam soil (25\%), Sand (25\%) & 50 \\
\hline Test 4 (T4) & Sodium bentonite clay and 50\% Sand & 50 \\
\hline Test 5 (T5) & Polythene Sheet & 0 \\
\hline
\end{tabular}


The composition of SBC is tested with sandy loam soil to overcome natural limitation of pure clay as a lining material. Three out of five tests were run on determining the most suitable combination of SBC with other materials to determine an effective lining material for seepage control particularly for the side walls of the experimental ponds (Figure 2). The selection of the composition of the layers was therefore, made considering the local availability of the material as well as technical aspects. For instance, wheat straw has been known to reduce cracking ability of the clay and traditionally used to apply on the ancient rooftops and walls as a water sealing agent. The straw fiber acts as reinforcement to control shrinkage cracks and to improve toughness of the earth plaster [18].

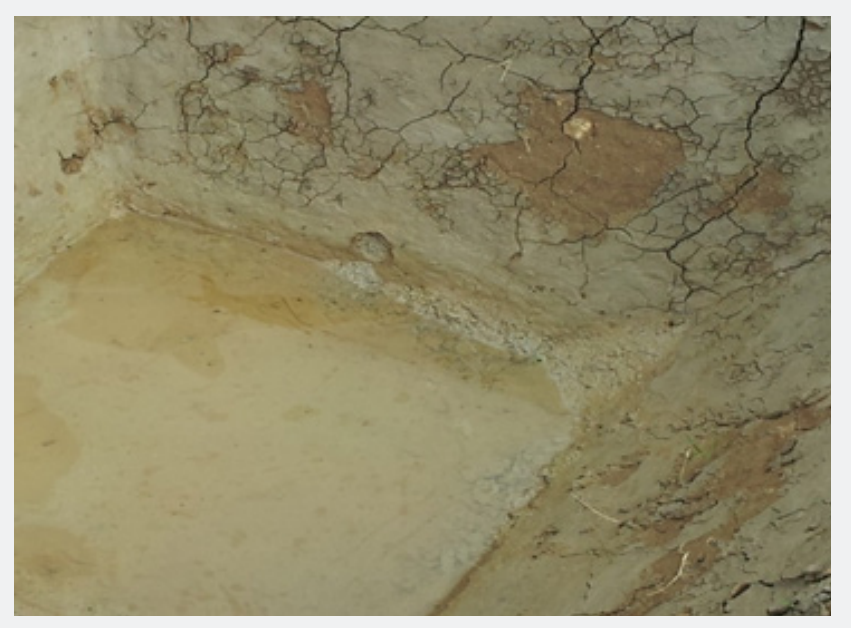

Figure 2: A view of the bentonite clay layer peeling off from the sidewalls.

Lining compositions were mixed by tilling or by hand raking as it is extremely important for the bentonite to be mixed uniformly with the soil. The composition mixture of the layer was mixed thoroughly and dough was left overnight to achieve saturation.
Pond beds and slopes were compacted by rolling. A fine and even layer of lining was ensured to stop leakages. All SBC combination linings were given 2-3 days for stabilization (Figure 3).

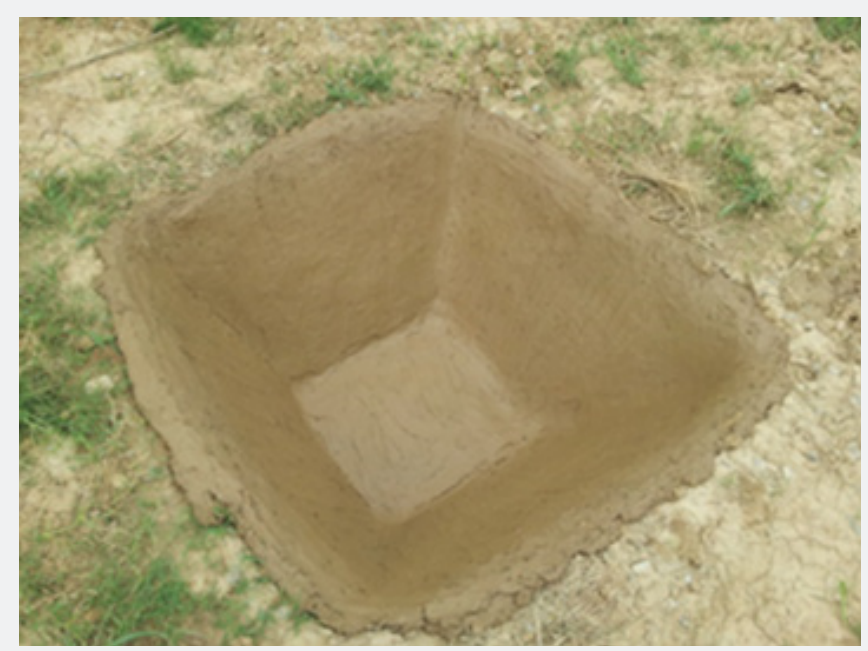

Figure 3: A view of the experimental earthen pond with treatment layer prior to experiment.

Seepage through the experimental ponds was recorded by erecting a staff rod into the middle of each pond (Figure 4). Water level in ponds was kept at $0.4 \mathrm{~m}$ with $0.06 \mathrm{~m}$ allowing for freeboard. Water was refilled in the pond every 10 minutes to keep water at the required level. Due to high initial seepages, the experimental ponds had to be refilled every 5 minutes. The decline in the water level was noted over time, initially at a time interval of 5 minutes and gradually increasing to 30 minutes. The total observation time for the experiment was 240 minutes ( 4 hours). Experiment on each test pond was repeated thrice. 


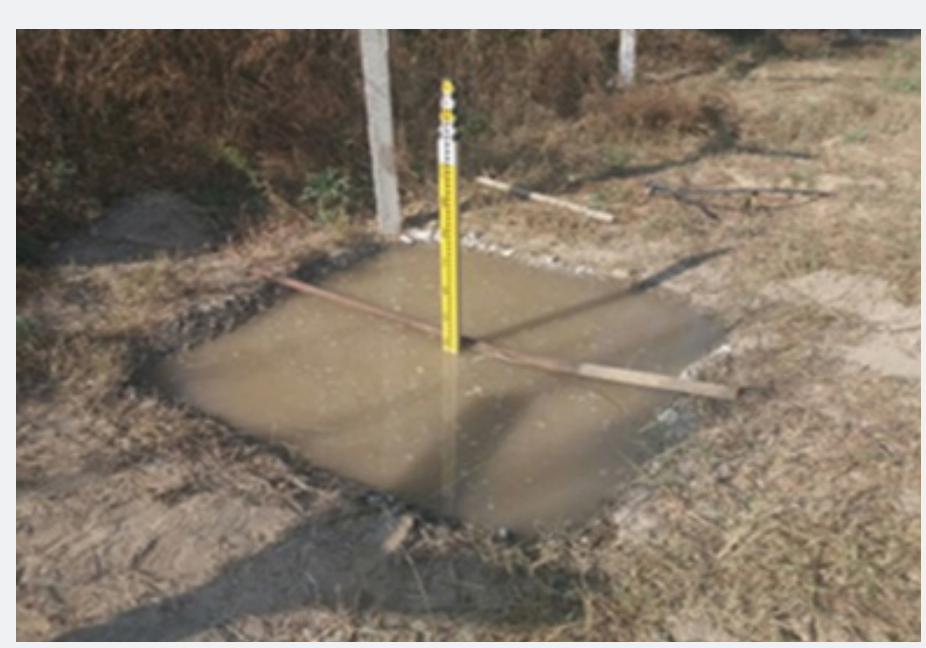

Figure 4: A view of the experiment under control treatment.

\section{Results and Discussion}

Experimental period mark three summer months with high evapotranspiration rate, higher average temperature and less rainfall (Figure 5). During the month of May 2016, highest temperature, pan evaporation up to $300 \mathrm{~mm}$ and least rainfall of the entire experimentation period was observed. A total of $0.6 \mathrm{~m}$ depth of water was lost to evaporation during experimentation period, a difference of cumulative precipitation $(300 \mathrm{~mm})$ and pan evaporation $(900 \mathrm{~mm})$. This level of evapotranspiration is $30 \%$ more than the water level maintained in the experimental ponds $(0.4 \mathrm{~m})$. This indicates that the probability of water loss to evapotranspiration is also high.

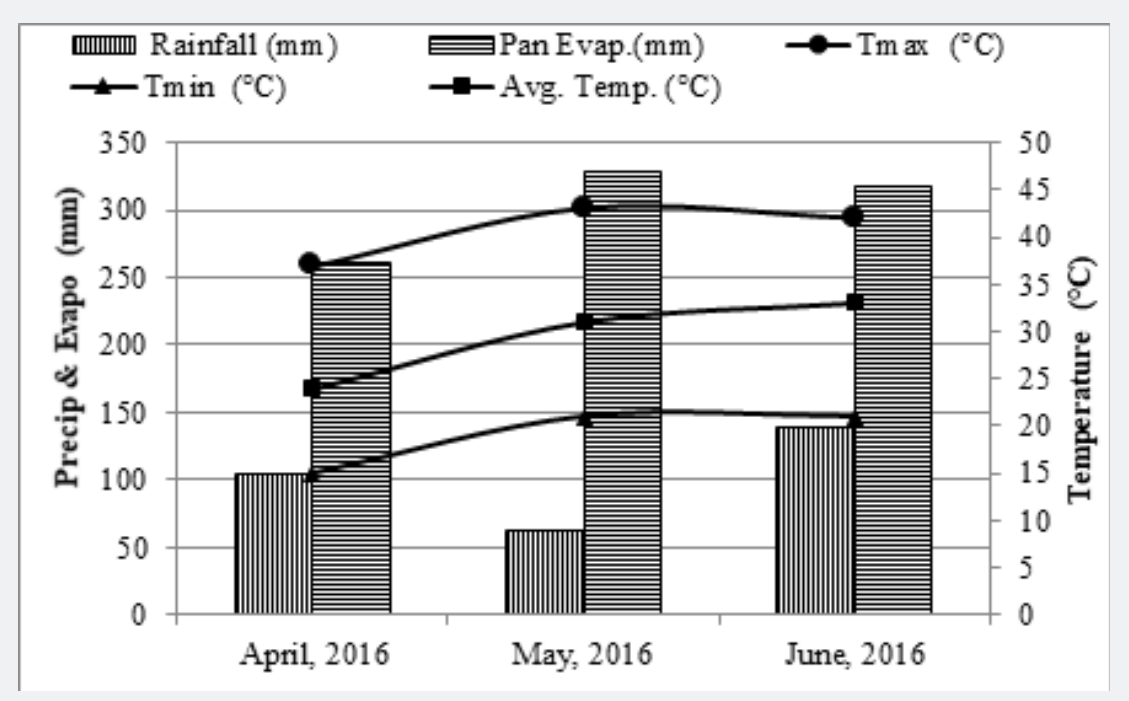

Figure 5: Climatic parameters observed during the experimental period (PCRWR Weather station data).

Infiltration rate in soil is a measure of the rate at which soil is able to absorb rainfall or irrigation. For the experimental plot, infiltration rate decreases with time. Initial infiltration rate is high as water comes in contact with soil, it decreases as the soil becomes saturated (Figure 6). Runoff and water storage in pond is the function of rate of infiltration of a particular soil. If the precipitation rate exceeds the infiltration rate, runoff will usually occur unless there is some physical barrier. It is related to the saturated hydraulic conductivity of the near-surface soil. It is an important characteristic of the soil which lets determine the prospects of in-situ rainwater harvesting and runoff generation under different rainfall events [19].

The soil of experimental site possess sandy loam characteristics, with clay (1.20\%), silt (48\%) and sand (50.80\%). The infiltration rate of the sandy loam soil is around $20-30 \mathrm{~mm} /$ 
hr [15]. Its water holding capacity is also low as can be seen in the moisture characteristic curve shown in Figure 7. The curve slope should be lowest in case of clay soil and highest for sandy strata
[17]. In case of experimental field, slope is mediocre representing sandy loam characteristics of the soil.

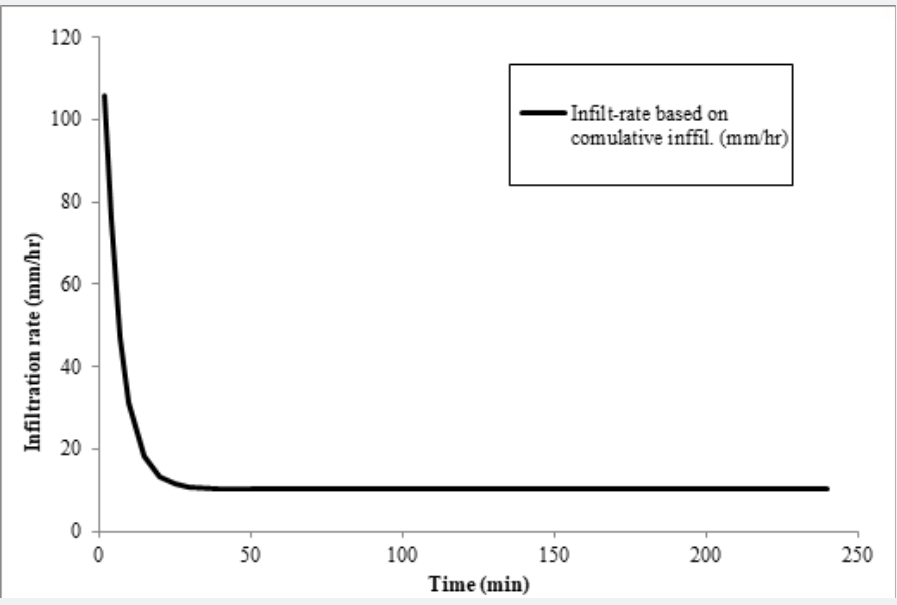

Figure 6: Measured Infiltration rate curve of the experimenal plot using Horton Model.

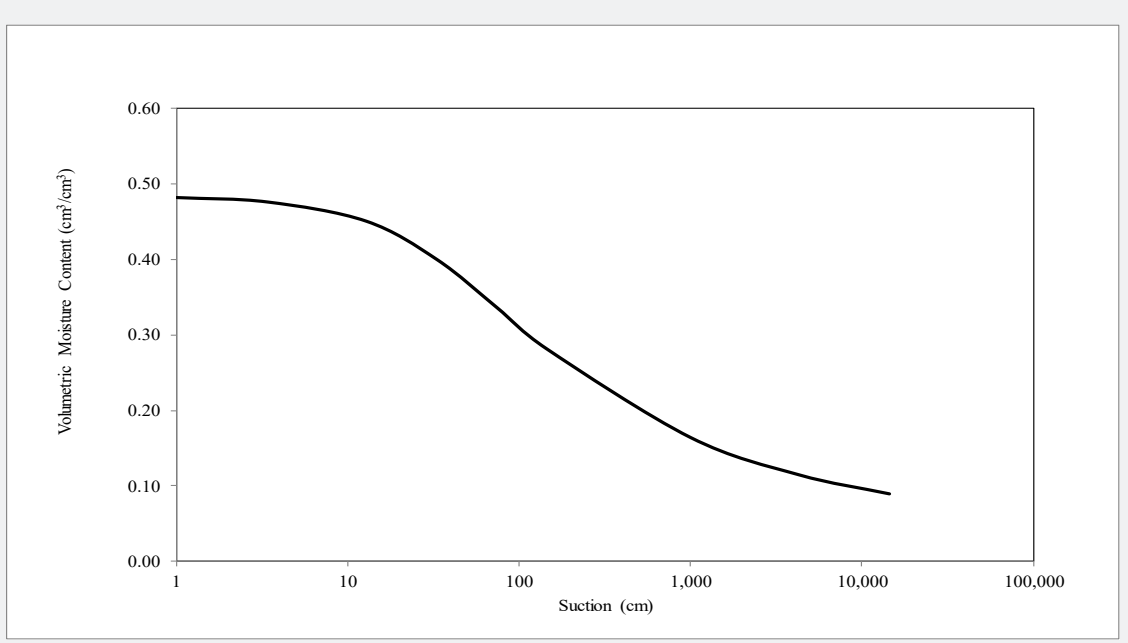

Figure 7: Soil moisture characteristic curve of the experimented soil.

Lower water holding capacity and high initial infiltration rate was evident in seepage from the earthen pond $\left(\mathrm{T}_{1}\right)$. This test was conducted to compare the significance level of SBC lining as compared to bare earthen pond and polythene lining. First test pond represented and confirmed the earlier determined infiltration rate in the field and soil-moisture retention curve in the laboratory. As is evident from the soil properties, seepage rate during the first hour of observation decreased from 200 to 70 $\mathrm{mm} / \mathrm{hr}$. The rate gradually declined and almost become steady after 180 minutes. After surpassing four hours of stagnation, seepage rate was recorded as $32 \mathrm{~mm} / \mathrm{hr}$ (Figure 8). It is also interesting to note that, in all three experiments $\mathrm{T}_{1}$, final seepage rate narrowed down to the same value. This value is about three times higher than that of observations made in $\mathrm{T}_{2}$ and $\mathrm{T}_{3}$.

In $\mathrm{T}_{2}$ (Figure 9), $2.5 \mathrm{~cm}$ thick layer of mixture composed of SBC (50\%), sandy loam soil (25\%) and chopped wheat straw (25\%) was applied on the bed and slopes. In $\mathrm{T}_{3}$ (Figure 10), chopped straw is replaced by sand (25\%). Seepage losses were higher in SBC mixed with wheat straw (T2) compared to sand (T3). Similar to $\mathrm{T}_{1}$, initial rate of seepage was high in $\mathrm{T}_{2}$ and $\mathrm{T}_{3}, 35 \mathrm{~mm} / \mathrm{hr}$ and $50 \mathrm{~mm} / \mathrm{hr}$ during first experiment, respectively. The initial rate of seepage reduced with increasing number of experiments on the same pond. In $\mathrm{T}_{2}$, finally stable seepage rate was recorded at about $10 \mathrm{~mm} / \mathrm{hr}$. Moreover, the pond sealing layer was found less cracked after drying of the moisture, which makes it a better lining over the others. 


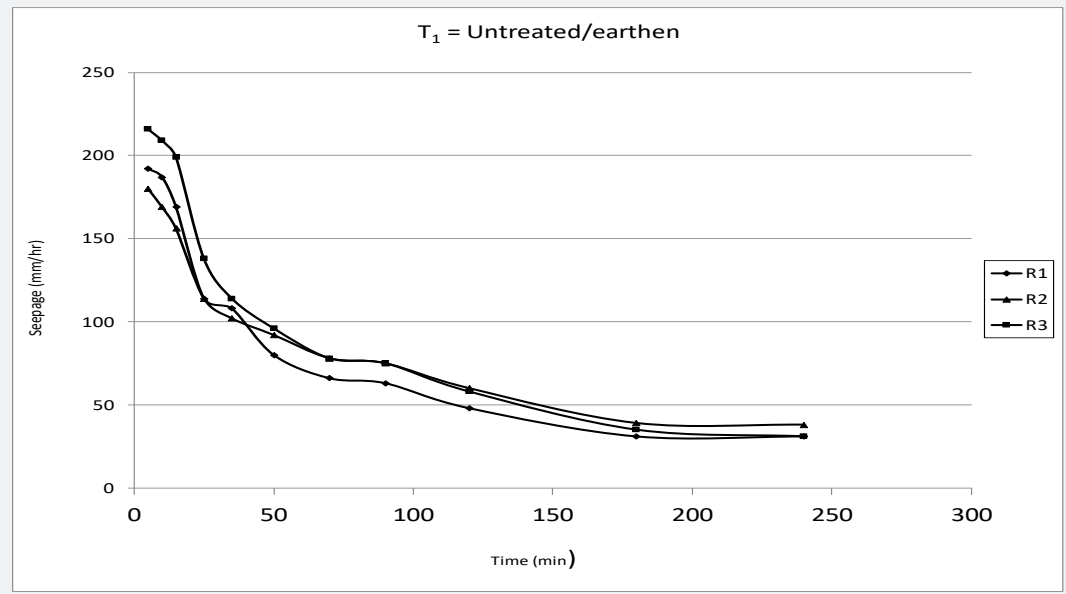

Figure 8: Seepage rates observed over time for the earthen experimental pond (T1).

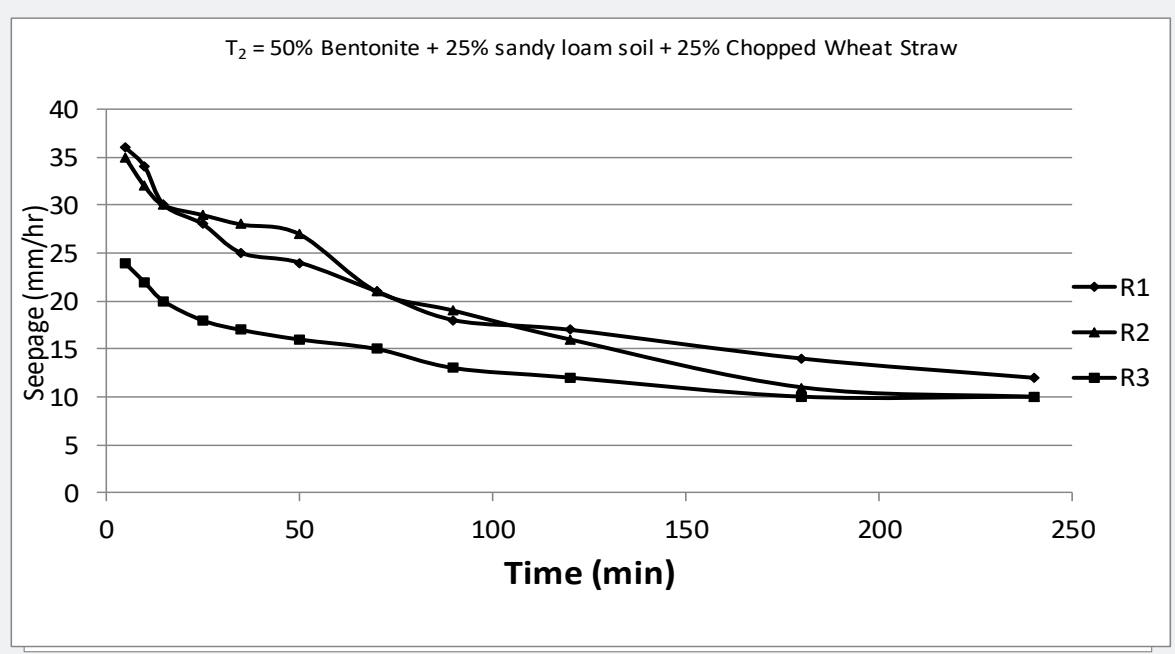

Figure 9: Seepage rates observed over time for the experimental pond $\left(\mathrm{T}_{2}\right)$.

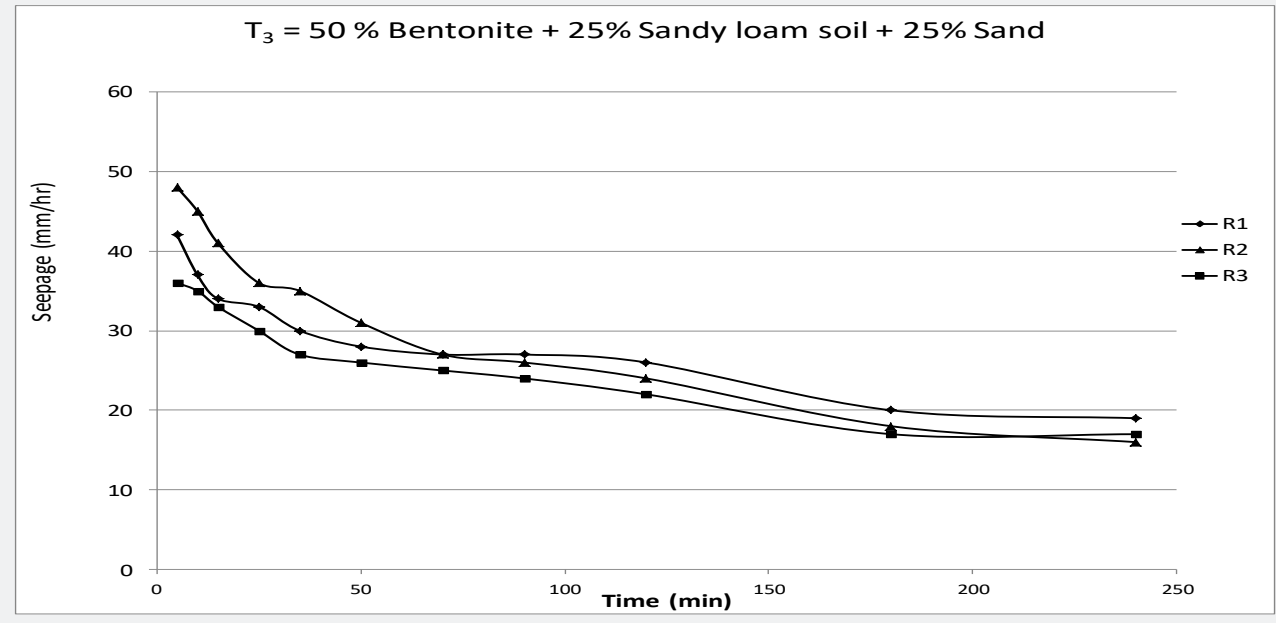

Figure 10: Seepage rates observed over time for the experimental pond (T3). 
It was also observed that, by the end of four hours long three experiments on each pond, the value of seepage losses seems to have coinciding, indicating a cut off time of four hours for sandy loam soil for reaching slowed rate of infiltration. In case of $\mathrm{T}_{1}$, sandy loam soil (100\%), in $\mathrm{T}_{2} \& \mathrm{~T}_{3}$, sandy loam soil (25\%) is also playing a key role slowing down seepage rate. However, in case of $\mathrm{T}_{3}$, where wheat straw is replaced with sand, last recorded seepage rate ranged between $6-19 \mathrm{~mm} / \mathrm{hr}$ during three experiments. This shows that wheat straw in combination with SBC is 60 percent more effective than sand for slowing down seepage losses.
Similarly, the layer stability on the sidewalls of the pond for this treatment was not good, as it was prone to slight cracking. In $\mathrm{T}_{4}$ (Figure 11), in which lining composition contained SBC (50\%) and sand (50\%), have recorded highest initial seepage rate among lined experimental ponds, exceeding $70 \mathrm{~mm} / \mathrm{hr}$. Results were further supported by [13] the seepage rate of $89 \mathrm{~mm} / \mathrm{hr}$ was observed in sand bentonite mixture in flowing experimental channel. Moreover, the finally stable seepage rate for the treatment was $22 \mathrm{~mm} / \mathrm{hr}$, which is also relatively higher than the $\mathrm{T}_{3}$.

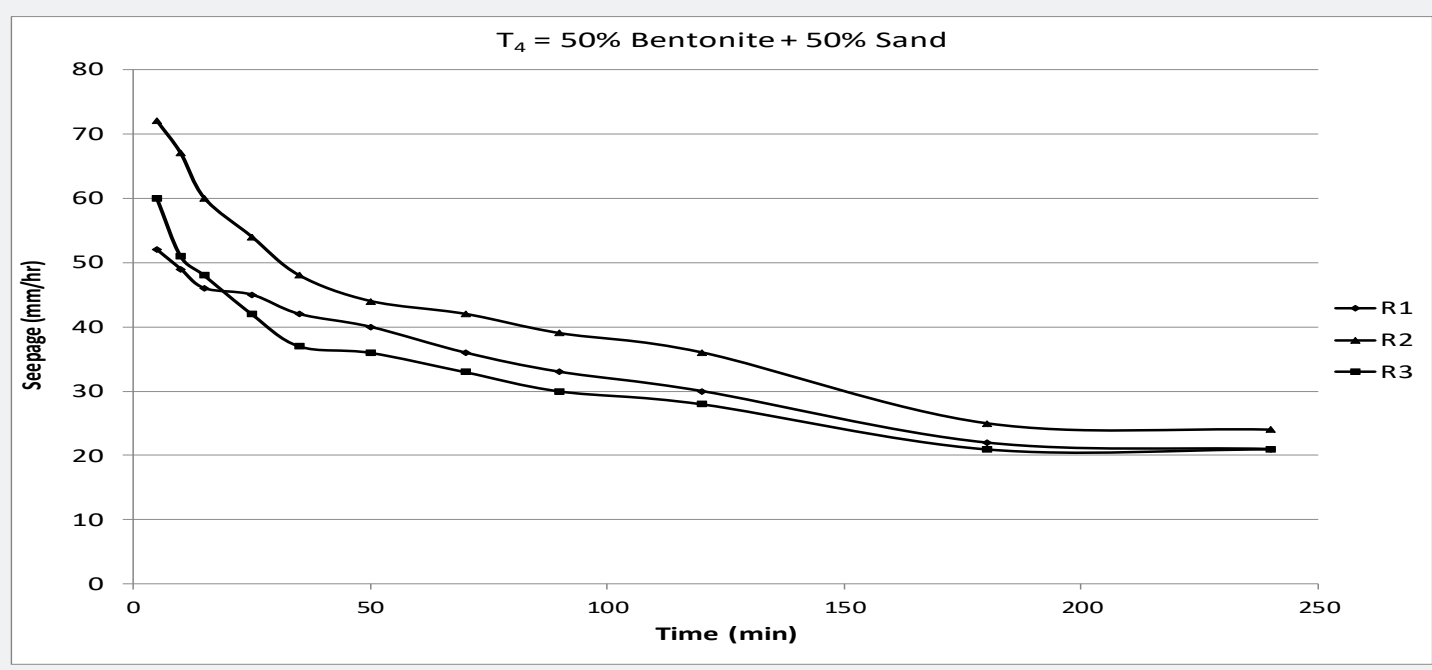

Figure 11: Seepage rates observed over time for the experimental pond (T4).

The $\mathrm{T}_{5}$ (Figure 12), non-uniformly perforated polythene sheet lining was used to determine seepage losses. The initial seepage rate in the polythene sheet treatment was as high as $23 \mathrm{~mm} / \mathrm{hr}$. Ideally speaking, the initial and final seepage rate of this treatment should have been the same. The finally stable seepage rate was about $10 \mathrm{~mm} / \mathrm{hr}$. An interesting finding of the treatment is that its stable seepage rate was equal to that of $\mathrm{T}_{2}$, which shows affectivity of the sodium bentonite clay treatment, in a certain combination, as a low cost solution to pond sealing.

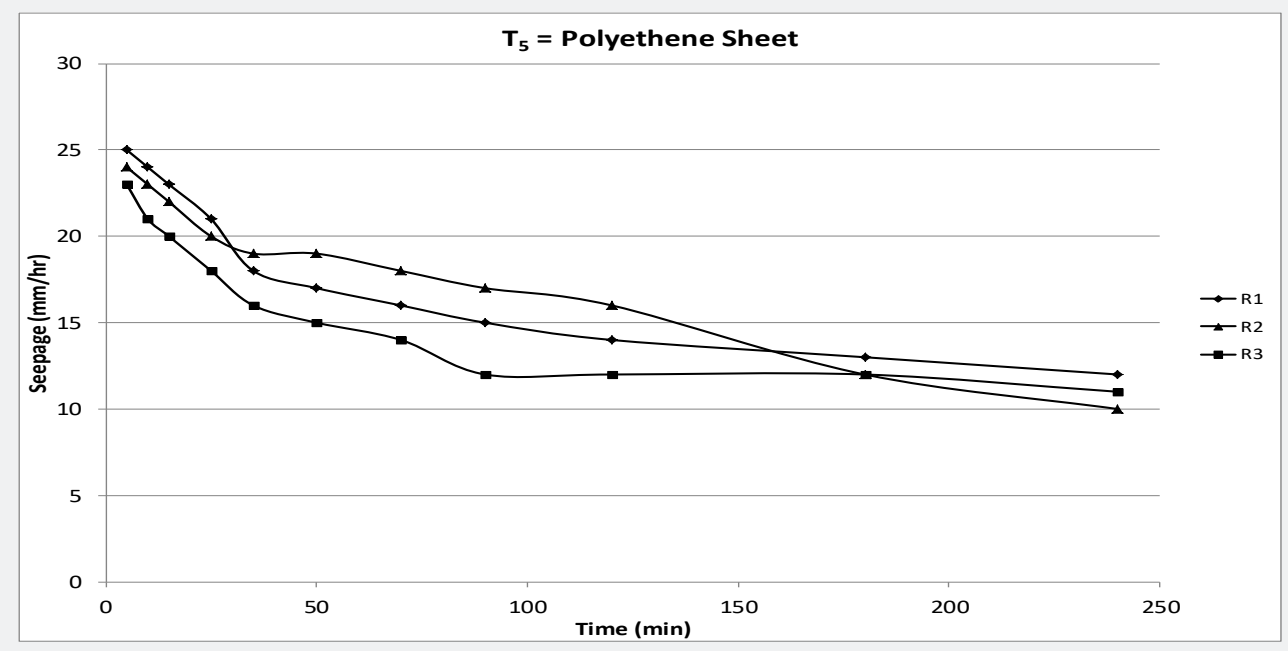

Figure 12: Seepage rates observed over time for the experimental pond (T5). 
Initially, experiment was not planned for a non-uniformly perforated sheet but these small pores developed accidently after laying sheet in the experimental pond. Perforation in polythene lining had appeared even in small sized experimental ponds. Therefore, in large sized ponds developed by the farmers, polythene lining may not be a practical option.

Seepage loss estimate from the experimental ponds was replicated thrice to minimize observational errors and observed seepages of all treatments are shown in (Figure 12). The seepages in lined ponds were two to four times less than that of bare earthen pit. In earthen pond, seepage rate was halved just 90 minutes after filling the pond with water. In case of lined ponds, seepage rate shows a steep decline over observation time. In these experiments, fourth hour is considered to be as "stabilizing point" as it marked a constant seepage rate. It has been observed that $\mathrm{T}_{2}$ and $\mathrm{T}_{5}$ gave out minimum seepages after four hours of ponding. Application of polythene sheet does not give out desirable results and therefore, may not be considered a viable option for larger ponds. SBC mixture layer must be thick up to four inches which synchronizes with earlier findings of $[12,13]$.

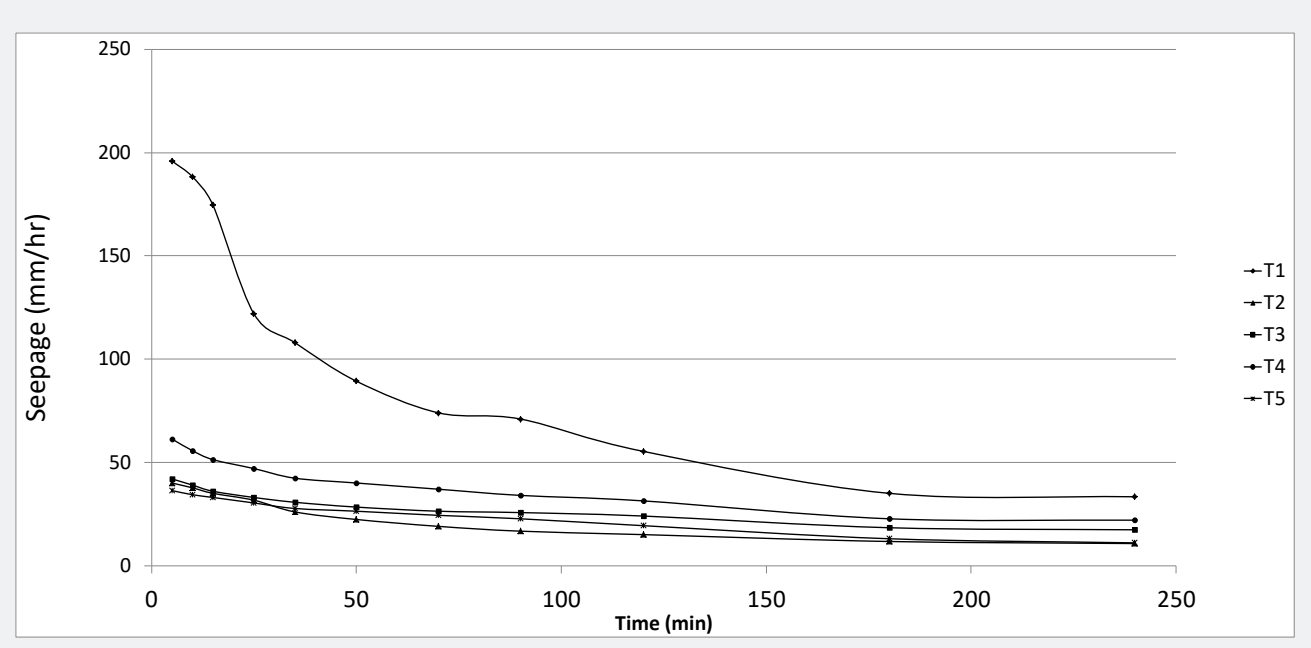

Figure 13: Seepage rates of all the tests over time.

The stable seepage rates obtained under the different treatments were compared applying " $\mathrm{t}$ " test and " $\mathrm{F}$ " test to determine significance of SBC as a preferable lining material. Different lining combinations at 95\% confidence interval $(\alpha$ $=5 \%$ ) was determined. The seepage rates of all four tests were significantly lower than that for the earthen ponds at $5 \%$ significance level (Table 2). As discussed above, there was no significant difference between SBC lining composition used in $\mathrm{T}_{2}$ and leaky polythene lining.

Table 2: Statistical analysis of seepage rates under different treatments in comparison to the control and polythene sheet treatments.

\begin{tabular}{|c|c|}
\hline Treatments Compared & Significant Difference \\
\hline $\mathrm{T}_{1} \& \mathrm{~T}_{2}$ & $\mathrm{~S}$ \\
\hline $\mathrm{T}_{1} \& \mathrm{~T}_{3}$ & $\mathrm{~S}$ \\
\hline $\mathrm{T}_{1} \& \mathrm{~T}_{4}$ & $\mathrm{~S}$ \\
\hline $\mathrm{T}_{1} \& \mathrm{~T}_{5}$ & $\mathrm{~S}$ \\
\hline $\mathrm{T}_{5} \& \mathrm{~T}_{1}$ & $\mathrm{~S}$ \\
\hline $\mathrm{T}_{5} \& \mathrm{~T}_{2}$ & $\mathrm{~N} . \mathrm{S}$ \\
\hline $\mathrm{T}_{5} \& \mathrm{~T}_{3}$ & $\mathrm{~S}$ \\
\hline $\mathrm{T}_{5} \& \mathrm{~T}_{4}$ & $\mathrm{~S}$ \\
\hline
\end{tabular}

S: Significant; N.S: Non-significant.
All the treatments of bentonite clay significantly reduced seepage in comparison to the earthen/control conditions. It was important to find out efficacy of certain bentonite clay treatments in comparison to the polythene sheet counterpart. So, the results were compared as shown in Table 2. It is therefore, recommended to opt for lining of SBC combination with chopped wheat straw and local soil to prevent pond water from seepage losses.

However, the seepages from polythene sheet treated pond $\left(\mathrm{T}_{5}\right)$ and that of $\mathrm{T}_{2}$ did not significantly differ from each other. It can therefore, be said that applying layer of $50 \%$ bentonite $+25 \%$ sandy loam soil $+25 \%$ chopped wheat straw is a good sustainable option for sealing the beds and sidewalls of the earthen ponds. Average monthly precipitation recorded during the experimental period (April-June) was $100 \mathrm{~mm}$ whereas rate of evaporation is three time higher. Therefore, this high evaporation rate is a potential limitation of these experiments. However, experiment time was four hours daily and was assumed to be constant for all the experiments. Therefore, this limitation seems to have no impact on results of this study.

The cost oflining is one of the importantfactors for the adoption of any technique. The cost includes the cost of material and the labour cost (Table 3). The cost of $\mathrm{T}_{3}$ was the lowest (US $\$ 0.39 / \mathrm{m}^{2}$ ). However, its seepage rate was on higher side $(17.33 \mathrm{~mm} / \mathrm{hr})$. The cost in $T_{2}$ (US $\$ 0.47 / \mathrm{m}^{2}$ ) was slightly higher than Treatment $\mathrm{T}_{3}$ 
but the seepage rate $(10.67 \mathrm{~mm} / \mathrm{hr})$ was substantially lower than $\mathrm{T}_{2}$. The other options like concrete and bricks lining may be more effective in controlling seepage. However, their costs are almost 10-15 times higher as compared to treatment $\mathrm{T}_{2}$.

Table 3: Cost estimation under various practices for seepage control.

\begin{tabular}{|c|c|c|c|}
\hline \multirow{2}{*}{ Treatments / Options } & \multicolumn{3}{|c|}{ Cost (US\$ / $\left.\mathbf{m}^{2}\right)$} \\
\hline & Labour & Material & Total \\
\hline $\mathrm{T}_{2}(50 \%$ bentonite $+25 \%$ sandy loam soil $+25 \%$ chopped wheat straw $)$ & 0.28 & 0.19 & 0.47 \\
\hline $\mathrm{T}_{5}$ (polythene sheet) & 0.22 & 0.64 & 0.86 \\
\hline $\mathrm{T}_{3}(50 \%$ bentonite $+25 \%$ sandy loam soil $+25 \%$ sand $)$ & 0.27 & 0.11 & 0.55 \\
\hline $\mathrm{T}_{4}(50 \%$ bentonite $+50 \%$ sand $)$ & 0.27 & 0.15 & 0.43 \\
\hline $\mathrm{T}_{1}$ (Untreated/Earthen) & - & - & - \\
\hline Concrete $(1: 2: 4)$ & 0.39 & 8.03 & 8.42 \\
\hline Brick & 0.39 & 3.46 & 3.85 \\
\hline
\end{tabular}

\section{Conclusion}

In the rainfed areas, rainwater harvesting ponds provide water for human, livestock and for small scale agriculture. However, their sustainability is threatened by seepage from the bottom and sides of the ponds. Lining with polythene, bricks and concrete are costly and require highly skilled labour to construct and maintain. Nevertheless, Sodium bentonite clay (SBC) can be used alone for lining of ponds or in combination with local soil or straw. It is cheap, locally available and can be applied with unskilled labour. However, its effectiveness varies according to the characteristics of the soil. A combination of SBC (50\%), sandy loam (25\%) and wheat straw (25\%) was found to be the most effective in reducing seepage losses from a pond.

\section{References}

1. Oweis T, Hachum A (2006) Water harvesting and supplemental irrigation for improved water productivity for dry farming systems in West Asia and North Africa. Agricultural Water Management 80(1-3): 57-73.

2. Mahmood A, T Oweisb, M Ashraf, A Majid, M Aftab, et al. (2015) Performance of improved practices in farmers' fields under rainfed and supplemental irrigation systems in a semi-arid area of Pakistan. Agricultural Water Management 155: 1-10.

3. Ashraf M (2016) Managing Water Scarcity in Pakistan: Moving Beyond Rhetoric. Proc. AASSA- PAS Workshop on Challenges in Water Security to Meet the Growing Food Requirement. Pak Acad Sci Islamabad, pp. 3-14

4. Ahmad S, Hussain Z, Qureshi AS, Majeed R, Saleem M (2004) Drought mitigation in Pakistan: Current Status and option for the future strategies. Working Paper 85. Colombo, Sri lanka: International Water Management Institute.

5. Uddin MJ, V Sravya, OB Abdullah (2017) Rain water harvesting (Farm Pond). International J of Emerging Res in Manage \& Tech 6(2): 22789359.

6. Ghimire SR, Johnston JM (2019) Sustainability assessment of agricultural rainwater harvesting: Evaluation of alternative crop types and irrigation practices. PLoS ONE 14(5): e0216452.

7. Julius JK, Prabhavathy AR, Ravikumar G (2013) Rainwater Harvesting (RWH)- A review. International Journal of Scientific and Engineering Research 4(8): 276-282.
8. Kesker A, Taji S, Ambhore R, Potdar S, Ikhar P, et al. (2016) Rainwater Harvesting-A Campus Study.

9. Deepkia S, Rao BK (2018) Farm Pond Lining Material- A review article. International Journal of Current Microbiology and Applied Science 7(11): 516-525.

10. Irshad A, AC Bashir, NH Butt (1993) Study on the Performance of Various Lining Materials. Proceedings Workshop on Canal Lining and Seepage, Lahore, Pakistan, pp. 301-321.

11. Bruce DA, Littlejohn GS, Naudts AMC (1997) Materials for ground treatment- A practitioner's guide. Proc Grouting: compaction, remediation \& testing, logan.

12. Nicholaichuk W (1978) Seepage control in excavated earthen reservoirs. Canadian Agricultural Engineering 20: 97-101.

13. Pfost DL, Williams D, Koeing R (1997) Reducing Pond Seepage. Agricultural Missouri University Guide. MU Extension, University of MU-Columbia. G 1555, p. 4.

14. Shehzad, TM Yaseen, M Afzal, K Khan, MA Rizwan, et al. (2017) Performance Evaluation of Sodium Bentonite. Technical Journal, University of Engineering and Technology (UET) Taxila, Pakistan 22(1).

15. Malik MA, M Ashraf (2017) Determining river basin hydraulic and physical characteristics. A manual. Pakistan Council of Research in Water Resources (PCRWR), p. 88.

16. Majeed S, Ali I, Zaman S, Ahmad S (2010) Productivity of Mini Dams in Pothwar Plateau: A Diagnostic Analysis. Research Briefings. 2(3). Natural Resources Division, Pakistan Agricultural Research Council, Islamabad.

17. Malik MA., M Ashraf, A Bahzad, AM Aslam (2019) Soil Physical and Hydraulic Properties of the Upper Indus Plain of Pakistan. Pakistan Council of Research in Water Resources (PCRWR), p. 70.

18. Taha A, Wei W (2010) An experimental study on shrinkage of earth plaster with natural fibres for straw bale buildings. International Journal of Sustainable Engineering, pp. 1-6.

19. Dagadu JS, Nimbalkar PT (2012) Infiltration studies of different soils under different Soil conditions and comparison of infiltration models with field data. International Journal of Advanced Engineering Technology. 
Your next submission with Juniper Publishers will reach you the below assets

- Quality Editorial service

- Swift Peer Review

- Reprints availability

- E-prints Service

- Manuscript Podcast for convenient understanding

- Global attainment for your research

- Manuscript accessibility in different formats ( Pdf, E-pub, Full Text, Audio)

- Unceasing customer service

Track the below URL for one-step submission https://juniperpublishers.com/online-submission.php 